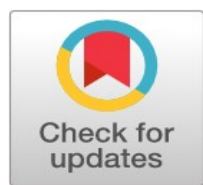

\title{
The relationship between organizational culture and employee motivation as moderated by work attitude
}

\author{
Hani Sakina Mohamad Yusof ${ }^{1}{ }^{*}$, Rudzi Munap ${ }^{2}$, Muhammad Izwan Mohd Badrillah ${ }^{3}$, \\ Noor Raihan Ab Hamid ${ }^{4}$, Romiza Md Khir ${ }^{5}$ \\ 1, 3 Universiti Teknologi Mara, Malaysia \\ 2, 4, 5 Unitar International University, Malaysia
}

\author{
Index Terms \\ Organizational culture \\ Employee motivation \\ Work attitude \\ Multinational \\ Automotive industries
}

Received: 17 October 2016

Accepted: 10 December 2016

Published: 27 February 2017

\begin{abstract}
The objective of this study was to examine the relationship between organizational culture and employee motivation as moderated by work attitude among the multinational automotive industries in Selangor. The dimensions of organizational culture are bureaucratic, innovative and supportive culture. The questionnaire was adopted from Abananeh (2010) for organizational culture, Chiang \& Jang (2008) for employee motivation and Susaeta et al. (2013) for items of work attitude. The items were then adapted to fit the feasibility of this study. In studying the relationship between organizational culture and employee motivation as moderated by work attitude, Pearson Product-Moment Correlation Coefficient and Hierarchical Regression Analysis were used. From the findings, it was found that all the dimensions in organizational culture had strong significant relationship with employee motivation. On the other hand, for moderating variable, work attitude does not significantly moderate the relationship between organizational culture and employee motivation.
\end{abstract}

(C) 2017 The Author(s). Published by TAF Publishing.

\section{INTRODUCTION}

Organizational culture is an important determinant of organizational success. Organizational culture is the workplace environment formulated through the interaction of employees at work. It can be learned and shared in the social environment and every field of human lives (Alkailani, Azzam \& Athamneh, 2012; Rijal, 2016) and encourages the innovative behaviour among members of the organization (Naranjo-Valencia, Jiménez-Jiménez \& Sanz-Valle, 2011). In trying to better understand the concept of organizational culture, several topologies had been developed. One of the topologies developed by (Wallach, 1983) categorizes organizational culture into three main types: bureaucratic, innovative and supportive. Bureaucratic is viewed as hierarchically structured, orderly, procedural and highly regulated, while innovative is seen as creative, enterprising, risk-taking and result oriented. Innovative culture also enhances the creation and implementation of new ideas and working methods in an organization. In a German manufacturing company Buech, Michel \& Sonntag (2010), emphasized that employees' motivation influences innovation. Employees become motivated when they are given a chance in sharing their innovative ideas with others. Supportive culture is characterized by equitable, sociable, trusting and collaborative behaviours (Taormina, 2008). According to Terje Karlsen (2011) a supportive organizational culture creates a well-performing management in day-to-day tasks and encourages a positive attitude in the top management. Mahal (2009) found that motivation is affected by the employee's work attitude. The value of the organizational culture influences the work attitude where it is useful in understanding and explaining the employee's

\footnotetext{
* Corresponding author: Hani Sakina Mohamad Yusof

†Email: hani_kina@yahoo.com.my
} 
motivation. Flavián \& Gurrea (2009) defined attitude as an individual's belief that a product, service or concept is a good idea and they show a clear tendency for that element.

\section{LITERAT URE REVIEW}

Wallach (1983) and Weng \& Yang (2016) said that to understand culture, it involves the understanding of the difference between the formal and informal rules, the way of doing things and the real way espoused. Culture will influence all the way people do the things where it will affect their norms and values. According to Ta ormina (2008) and in the Journal of Leadership and Organization Development, organizational culture can be defined as shared by a particular group of people on common believes, values and behaviours in an organization. Organizational culture gives a sense of what the values of the organization are and how things should be done within the organization. Dubkevics \& Barbars (2010) said bureaucratic culture is based on control, power, oriented, cautious, established, solid, regulated, ordered, structured, procedural and hierarchical. According to Hall (as cited in Raub, 2008), bureaucratic is a formalization in decision making power that involves pre-programming of behaviour by the organization which drives the rules, regulations and standard operating procedures in an organization.

This bureaucratic culture is usually based on control and power given by the authority. Steele \& Murray (2004) and Na Ayutthaya, Tuntivivat \& Prasertsin (2016) said that innovative is a creative environment that changes the device or process to something new that follows the rules of the organization. Besides, the innovative culture also includes the willingness among corporate managers to take risks, wide-spread participation amongst members of the firm, stimulating creativity and shared responsibility. Rasool, Kiyani, Aslam, Akram \& Rajput (2012) stated that supportive culture is described as teamwork, trusting, encouraging work and people-oriented environment. This kind of attitude is good in supporting each other when performing a task. Terje Karlsen (2011) said that supportive culture can create a good communication among the employees in sharing the information which leads to effective management. This view is supported by Müller \& Turner (2007) who identified communication is the most critical factor in building a supportive culture for effective project management and project success. Roos \& Van Eeden (2010), labelled motivation as determinants of the choice to expand a certain amount of effort and the choice to persist in expanding effort over a period of time, the choice to initi- ate effort on a certain task. How and why people behave the way they do on the job will explain the personal and workplace characteristics (Roos \& Van Eeden, 2010). Kappagoda (2012) stated that work attitude can be found on how an individual managed his or her work. Individuals with positive attitude will satisfy their performance and those who are dissatisfied with, have a negative attitude towards it. Positive attitude can inspire and motivate others to become more independent and open in accepting any decision from top management. Employees with positive work attitude will expect a positive outcome and results that make them more successful and become more motivated while doing a task. The theoretical framework above explained the relationship between organizational culture and employee motivation as moderated by work attitude.

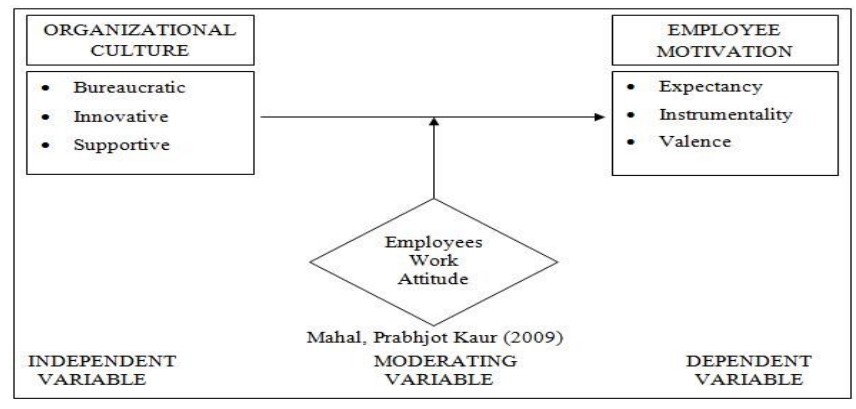

FIGURE 1. Conceptual Framework on Moderating effect of Employees' Work Attitude between Organizational Culture and Employee Motivation

\section{RESEARCH METHODOLOGY}

The instrument for this study was a questionnaire which was adapted from Ismail Ababaneh (2010) for organizational culture, Chiang \& Jang (2008), for employee motivation and Susaeta et al. (2013) for items of work attitude. A survey was conducted to the employees of multinational industries, categorised as automotive, located in the state of Selangor. From a population of 1196, a total of 357 questionnaires were distributed to the selected samples. A total of $30 \%$ for the population is taken as a sample size for this study. A total of 260 questionnaires were received and that yields 72 percent response return rate. The questionnaire was made up of four different sections. Section A captures the demographic information of the respondents. Sections $\mathrm{B}, \mathrm{C}$ and $\mathrm{D}$ required them to rate their organizational culture, motivation and work attitude with a 5-point Likert scale measuring from 1, being "Strongly Disagree" to 5 , "Strongly Agree". The validation process of instrument is to ensure that the questionnaire is relevant to the respondents 
(Sekaran \& Bougie, 2010). Validity refers to how well an instrument that is developed measures what it intends to measure (Sekaran \& Bougie, 2010). This study uses both the face and content validity. For face validity, the items were built through discussion with colleagues who had strong management background. Content validity is important to indicate the extent to which a test represents the universe of items from which it was drawn and it is very helpful when evaluating the usefulness of achievement tests (Salkind, 2006). The content validity identifies a total of three experts from the discipline of management with the main purpose of ensuring that the instrument is in accordance with the research objectives and research questions stipulated in the study.

\section{RESEARCH FINDINGS}

Table 1 displays the descriptive statistics for the demographic profile of the respondents. The table shows that a total of $51.9 \%$ of the respondents are male as opposed to $48.1 \%$ female. In terms of race, majority of the respondents, $85.8 \%$ are Malays. While, in the age group, $38.1 \%$ are at the range of 28-38 years old. Employee possessing bachelor's degree is the biggest number of respondents who participated in this study, comprising of $37.7 \%$. It was also found that most of the respondents, that is, $35.8 \%$ served as executive and $43.5 \%$ are from the middle level management. A total of $37.7 \%$ of them had a working experience of less than 5 years.

TABLE 1. Demographic profile of the respondents $(n=260)$

\begin{tabular}{|c|c|c|c|}
\hline Respondents' Profile & Classification & Frequency & Percent \\
\hline \multirow[t]{2}{*}{ Gender } & Male 7 & 112 & 51.9 \\
\hline & Female & 108 & 48.1 \\
\hline \multirow[t]{4}{*}{ Race } & Malay & 223 & 85.8 \\
\hline & Chinese & 18 & 6.9 \\
\hline & Indian & 15 & 5.8 \\
\hline & Others & 4 & 1.5 \\
\hline \multirow[t]{4}{*}{ Age } & 18-27 years old & 95 & 36.5 \\
\hline & 28-38 years old & 99 & 38.1 \\
\hline & $39-49$ years old & 55 & 21.2 \\
\hline & Above 50 years old & 11 & 4.2 \\
\hline \multirow[t]{7}{*}{ Highest Education } & Doctor of Philosophy & 6 & 2.3 \\
\hline & Master & 29 & 11.2 \\
\hline & Bachelor Degree & 98 & 37.7 \\
\hline & Diploma & 63 & 24.2 \\
\hline & Certificate & 21 & 8.1 \\
\hline & STPM & 10 & 3.8 \\
\hline & SPM & 33 & 12.7 \\
\hline \multirow[t]{7}{*}{ Present Position } & Director & 2 & 0.8 \\
\hline & Manager & 15 & 5.8 \\
\hline & Executive & 93 & 35.8 \\
\hline & Secretary & 11 & 4.2 \\
\hline & Administrative Assistant & 34 & 13.1 \\
\hline & Clerk & 41 & 15.8 \\
\hline & Others & 64 & 24.6 \\
\hline \multirow[t]{3}{*}{ Level of Management } & Top Level Management & 2 & 0.8 \\
\hline & Middle Level Management & 113 & 43.5 \\
\hline & Lower Level Management & 145 & 5 \\
\hline \multirow[t]{5}{*}{ Working Experience } & Less than 5 years & 98 & 37.7 \\
\hline & 6-10 years & 68 & 26.2 \\
\hline & 11-15 years & 42 & 16.2 \\
\hline & $16-20$ years & 21 & 8.1 \\
\hline & More than 21 years & 31 & 11.9 \\
\hline
\end{tabular}

ISSN: 2414-309X

DOI: $10.20474 /$ jabs-3.1.3
TABLE 2 . Cronbach's alpha results for all variables

\begin{tabular}{lcc}
\hline \hline Variables & Cronbach's Alpha & No, of Items \\
\hline Independent Variables (Organizational Culture) & .793 & 15 \\
- Bureaucratic & .866 & 5 \\
- Innovative & .859 & 5 \\
- Supportive & .836 & 5 \\
Dependent Variable & & \\
- Employee Motivation & .966 & 12 \\
Moderating Variable & & \\
- Work Attitude & .812 & 7 \\
\hline \hline
\end{tabular}

The Cronbach's Alpha results for all variables are shown in Table 2 above. The finding of this study shows that all variables have higher value of reliability analysis whereby all variables have greater than 0.7 Cronbach's alpha coefficient. The Cronbach's alpha for the dependent variable for employee motivation was .966. Meanwhile, independent variable for organizational culture was .793, a value of .866 for bureaucratic, innovative .859 and .836 for supportive. The alpha value for the moderating variable was .812 . Therefore, based on the findings of reliability analysis, the measurements used in this study were highly reliable and completely valid for further analysis.

TABLE 3 . Correlation coefficient analysis between organizational culture and employee motivation

\begin{tabular}{lcc}
\hline \hline & & Employee Motivation \\
\hline & Pearson Correlation & $0.546^{* *}$ \\
Bureaucratic Culture & Sig. (1-tailed) & .000 \\
& N & 260 \\
Innovative Culture & Pearson Correlation & $0.724^{* *}$ \\
& Sig. (1-tailed) & .000 \\
Supportive Culture & N & 260 \\
& Pearson Correlation & $0.645^{* *}$ \\
& Sig. (1-tailed) & .000 \\
& $\mathrm{~N}$ & 260 \\
\hline \hline
\end{tabular}

The correlation coefficient analysis was performed to examine the relationship between organizational culture and employee motivation among multinational automotive industries' employees in Selangor. The results indicated that innovative culture is the main variable indicating that there is a positive strong significant relationship between innovative culture and employee motivation $(r=0.724$, $p<0.05)$, followed by supportive culture $(r=0.645 . p<0.05)$ 
and bureaucratic culture $(r=0.546, r=0.05)$.

TABLE 4 . Hierarchical regression analysis between moderating effect of work attitude on the relationship between organizational culture and employee motivation

\begin{tabular}{|c|c|c|c|}
\hline \multirow[t]{2}{*}{ Variables } & \multicolumn{3}{|c|}{ Employee Motivation } \\
\hline & Model 1 Standard $\beta$ & Model 2 Standard $\beta$ & Model 3 Standard $\beta$ \\
\hline \multicolumn{4}{|l|}{ Independent Variables } \\
\hline - Bureaucratic Culture & $0.374^{* * *}$ & $0.374^{* * *}$ & 0.094 \\
\hline - Innovative Culture & $0.264^{* * *}$ & $0.266^{* * *}$ & $1.241^{*}$ \\
\hline - Supportive Culture & 0.062 & 0.019 & 0.013 \\
\hline \multicolumn{4}{|l|}{ Moderating Variables } \\
\hline - Work Attitude & & 0.072 & 0.656 \\
\hline \multicolumn{4}{|l|}{ Interaction } \\
\hline \multicolumn{4}{|l|}{ - Work Attitude X } \\
\hline Bureaucratic Culture & & & 0.370 \\
\hline \multicolumn{4}{|l|}{ - Work Attitude X } \\
\hline Innovative Culture & & & $-1.246^{*}$ \\
\hline \multicolumn{4}{|l|}{ - Work Attitude X } \\
\hline Supportive Culture & & & 0.015 \\
\hline $\mathrm{R}$ & 0.567 & 0.570 & 0.580 \\
\hline $\mathrm{R}^{2}$ & 0.322 & 0.325 & 0.337 \\
\hline Adjusted $\mathrm{R}^{2}$ & 0.314 & 0.314 & 0.318 \\
\hline F Change & 40.449 & 1.227 & 1.497 \\
\hline Significant F Change & $0.000^{* * *}$ & 0.269 & 0.216 \\
\hline Durbin Watson & & & 1.575 \\
\hline
\end{tabular}

Table 4 above shows the finding of the moderating effect of work attitude on the relationship between organizational culture and employee motivation. From the findings, Model 1 explains $32.2 \%$ of the variance. Model 2 explains $32.5 \%$ of variance and additionally $0.2 \%$ higher than variance in the Model 1. Model 3 explains 33.7\% of the variance, $1.2 \%$ increment in the variance explained. Model 3 shows significant $F$ change $(p<0.05, F=0.216)$.

Referring to Model 1, the finding indicated that the two dimensions of independent variables; bureaucratic and innovative culture are significant predictors of employee motivation. Meanwhile, supportive culture does not act as a significant predictor to employee motivation. The value for bureaucratic culture is $(\beta=0.374, p<0.01)$, innovative culture $(\beta=0.264, p<0.01)$ and supportive culture $(\beta=0.062$, $\mathrm{p}>0.05)$. In interpreting the moderating existence of work attitude with employee motivation, Model 2 illustrates the value for the moderating variable. The value for work attitude as moderator is $(\beta=0.072, p>0.05)$. Thus, work attitude can be regarded as it is not having direct significant relationship with employee motivation as dependent variable.

Pertaining to the moderating effect of work attitude on the relationship between organizational culture and employee motivation, Model 3 indicates the value of work attitude. Work attitude indicates $(\beta=0.656, p>0.05)$. Thus, work attitude can be regarded as not having direct significant relationship with organizational culture and employee motivation. Therefore, it can be summarized that work attitude significantly moderates the relationship between innovative culture and employee motivation. Cramm, Srating, Bal \& Nieboer (2013) said that innovative culture reflects attitude of the employees as well as the organization which will provide a link between effective practice and high quality of productivity. It is not only knowledge and processes needed in creating a culture, but attitude of employees is also important for innovation to occur (Škerlavaj, Song \& Lee, 2010). However, work attitude does not significantly moderate the relationship between bureaucratic and supportive culture to employee motivation.

\section{CONCLUSION}

It can be concluded that organizational culture has an impact towards the employees' motivation. Culture in an organization is really important in developing a good level of motivation among the employees. From the findings of this study, it is suggested to the managers to continue with the current practices of bureaucratic, innovative and supportive culture in their organization. For future study, it is suggested to consider other elements that could affect the organizational culture. Those elements are communication, leadership, decision making and empowerment, education and development.

\section{REFERENCES}

Alkailani, M., Azzam, I.A., \& Athamneh, A.B. 2012. Replicating hofstede in Jordan: Ungeneralized, reevaluating the Jordanian culture. International Business Research, 5(4): 71-80. DOI: 10.5539/ibr.v5n4p71

Buech, V.I., Michel, A., \& Sonntag, K. 2010. Suggestion systems in organizations: What motivates employees to submit sug- gestions? European Journal of Innovation Management, 13(4): 507-525. D0I: 10.1108/14601061011086311 Chiang, C.F., \& Jang, S.S. 2008. An expectancy theory model for hotel employee motivation. International Journal of Hospi- $\quad$ tality Management, 27(2): 313-322. DOI: 10.1016/j.ijhm.2007.07.017

Cramm, J.M., Strating, M.M., Bal, R., \& Nieboer, A.P. 2013. A large-scale longitudinal study indicating the importance of per- ceived effectiveness, organizational and management support for innovative culture. Social Science \& Medicine, 83: $\quad$ 119-124. DOI: 10.1016/j.socscimed.2013.01.017 
Dubkevics, L., \& Barbars, A. 2010. The role of organizational culture in human resource management. Human Resource Management \& Ergonomics, 4: 1-10.

Flavián, C., \& Gurrea, R. 2009. Users' motivations and attitude towards the online press. Journal of Consumer Marketing, 26(3): 164-174. DOI: 10.1108/07363760910954109

Ismail Ababaneh, R. 2010. The role of organizational culture on practising quality improvement in Jordanian public hospi- $\quad$ tals. Leadership in Health Services, 23(3): 244-259. DOI: 10.1108/17511871011061064

Kappagoda, S. 2012. The impact of work related attitudes on task and contextual performance: A comparative study in public and private banks in Sri Lanka. International Journal of Research in Commerce, Economics \& Management, 2(9): 23-27.

Mahal, P. K. 2009. Organizational culture and organizational climate as a determinant of motivation. IUPJournal of Man- agement Research, 8(10): 38-51.

Müller, R., \& Turner, R. 2007.The influence of project managers on project success criteria and project success by type of project. European Management Journal, 25(4): 298-309. DOI: 10.1016/j.emj.2007.06.003

Naranjo-Valencia, J.C., Jiménez-Jiménez, D., \& Sanz-Valle, R. 2011. Innovation or imitation? The role of organizational cul- $\quad$ ture. Management Decision, 49(1): 55-72. DOI: 10.1108/00251741111094437

Na Ayutthaya, J.S., Tuntivivat, S., \& Prasertsin, U. 2016. The effect of positive psychological capital and organizational climate on service quality: The mediation role of work engagement of hotel service employees in Ratchaburi province. Journal of Administrative \& Business Studies, 2(4), 167-176.

Rasool, S., Kiyani, A.A., Aslam, M.J., Akram, M.U., \& Rajput, A.A. 2012. Impact of organizational culture on employee's career salience: An empirical study of banking sector in Islamabad, Pakistan. International Journal of Business \& Social Sci- ence, 3(7): 299-306.

Raub, S. 2008. Does bureaucracy kill individual initiative? The impact of structure on organizational citizenship behavior in the hospitality industry. International Journal of Hospitality Management, 27(2): 179-186.

DOI: $10.1016 /$ j.ijhm.2007.07.018

Roos, W., \& Van Eeden, R. 2008. The relationship between employee motivation, job satisfaction and corporate culture. SA Journal of Industrial Psychology, 34(1): 54-63. D0I: 10.4102/sajip.v34i1.420

Rijal, S. 2016. The influence of transformational leadership and organizational culture on learning organization: A comparanalysis of the IT sector. Thailand. Journal of Administrative \& Business Studies, 2(3), 121-129.

Salkind, N.J. 2006. Exploring research . Upper Saddle River, NJ: Pearson Education Inc.

Sekaran, U., \& Bougie, R. 2010. Research methods for business: A skill building approach. New York, NY: John Wiley and Sons Ltd Publication.

Škerlavaj, M., Song, J.H., \& Lee, Y. 2010. Organizational learning culture, innovative culture and innovations in South Korean firms. Expert Systems with Applications, 37(9): 6390-6403. DOI: 10.1016/j.eswa.2010.02.080

Steele, J., \& Murray, M. 2004. Creating, supporting and sustaining a culture of innovation. Engineering, Construction \& Architectural Management, 11(5): 316-322. DOI: 10.1108/09699980410558502

Susaeta, L., Ramon Pin, J., Idrovo, S., Espejo, A., Belizón, M., Gallifa, A., \& Avila Pedrozo, E. 2013. Generation or culture? Work attitude drivers: An analysis in Latin America and Iberian countries. Cross Cultural Management: An International Journal, 20(3): 321-360. DOI: 10.1108/CCM-12-2011-0126

Ta ormina, R.J. 2008. Interrelating leadership behaviors, organizational socialization, and organizational culture. Leader\& Organization Development Journal, 29(1): 85-102. DOI: 10.1108/01437730810845315

Terje Karlsen, J. 2011. Supportive culture for efficient project uncertainty management. International Journal of ManagProjects in Business, 4(2): 240-256. DOI: 10.1108/17538371111120225

Wallach, E.J. 1983. Individuals and organizations: The cultural match. Training \& Development Journal, 37(2): 28-36. Weng, H.Y., \& Yang, C.H. 2016. Culture conservation and regeneration of traditional industries derived by tourism factory- Case study of Kw ong xi paper factory in Ta iwan. International Journal of Humanities, Arts \& Social Sciences, 2(5): $172-180$. 